\title{
Play-making with migrant farm workers in Ontario, Canada: a kinesthetic and embodied approach to qualitative research
}

\section{J Adam Perry}

McMaster University, Canada

Published in Qualitative Research, 2018,

Vol 18(6), 689-705 


\begin{abstract}
This article is a reflection on the use of theatre creation in qualitative research with migrant farm workers in Ontario, Canada. In this article I examine how the fundamentally embodied and kinesthetic dimensions of seasonal agricultural workers' lives in Canada highlight the need to seek out and develop corresponding embodied approaches that are able to access and accurately represent the fraught and dynamic nature of workers' experiences. I bring together ideas from both arts-informed research and participatory action research, and I examine how engaging research participants directly in collective theatre creation can effectively disrupt accepted ways of being and offer an important intervention on worker habitus. I reflect on how through incorporating an element of playcreation in the qualitative research process, I was able to a) access forms of knowledge that may otherwise have remained tacit and b) offer a disruption of the norms of isolation and antagonism endemic to daily life in Canada's Seasonal Agricultural Worker Program.
\end{abstract}

\title{
Introduction
}

This article is concerned with developing an approach to participatory qualitative research that prioritizes embodied knowledge and participant voice, and which offers the possibility of critical social intervention. The article recounts the design and implementation of a

theatre-based research project with agricultural workers who participate in Canada's Seasonal Agricultural Worker Program (SAWP). The SAWP is an international bi-lateral labour migration program between Canada, Mexico and several Caribbean countries. The SAWP has been in existence since 1966, making it the oldest incarnation of Canada's Temporary Foreign Worker Program, a labour migration system that has been both growing exponentially and attracting a great deal of criticism in recent years. This article is a reflection on how to develop a critical, action-oriented approach to examining the perspectives and experiences of a population that is largely hidden. Specifically, I undertake an experiment in the use of artistic methods to consider different ways in which social science research can best capture the effects of public policies and organizational practices on the lives of a group of workers whose voice is typically neglected from discussions of social policy.

Unlike forms of performance ethnography that focus on the artistic dissemination of collected ethnographic data, this project employed popular theatre-style techniques directly with research participants. This article finds that by incorporating a kinesthetic, embodied, and highly participatory approach to gathering qualitative data, I was able to approach workers as both 'knowers' and embodied subjects, in turn provoking a critical disruption of worker habitus. The article describes how workers' engagement with dramatic movement, collective play-creation, and subsequent small group discussions offered a unique method for both uncovering tacitly held knowledge and intervening on 
accepted ways of being. I argue throughout this article that this type of knowledge could not be produced solely through more traditional forms of qualitative research methods, such as semi-structured interviews or participant observation, thus offering a compelling example of what Denzin (2009: 255) has referred to as a 'critical performance pedagogy that matters'. This article contributes to emerging debates on the use of the arts in qualitative research, particularly to nascent discussions on how and why to incorporate performative techniques in the realm of fieldwork, as opposed to dissemination. This article also contributes to current discussions in the area of precarious work (Mirchandani et al., 2016; Quinlan, 2011) that focus on the need to develop innovative research methods that de-emphasize a deficit approach to understanding workers' life worlds and instead highlight worker agency (Tuck, 2008). This is an area in which access to workers can be challenging, particularly when labour precarity intersects with precarious citizenship status, as is the case with temporary foreign workers in Canada. Therefore, by providing a detailed account of a participatory and embodied approach to engaging this population, this article provides a unique contribution to the development of worker-centred research methods in this area.

The article begins with an examination of why it is important to incorporate an embodied and kinesthetic approach to qualitative research with migrant farm workers in Canada. In this section I argue that an investigation of workers' lives in the SAWP must incorporate an embodied approach to knowledge production - one that recognizes a need to address forms of control and discipline endemic to state-managed labour migration in industries that require so-called 'low-skilled' labour, such as agriculture. Specifically, I explore how Canada's SAWP regulations and practices aimed at limiting the physical mobility of workers' bodies through the tethering of workers to their worksites through- out the duration of their contracts highlight the need to approach workers not just as 
research informants, but as embodied subjects. This is followed by a review of performance-oriented ethnography, with a focus on how theatre creation in qualitative research can integrate a dialogic, participatory and action oriented approach that can generate rich and nuanced understandings of workers' daily lives and present a challenge to the accepted norms of control. In the next sections I present and discuss some key moments from my research. These sections engage directly with workers' creation of a play that portrays the true-to-life experiences of a new worker to Canada's SAWP. I provide an analysis of workers' own engagement with play creation in order to examine how a kinesthetic and embodied approach to qualitative research can a) enhance workers' voice and access forms of knowledge that would otherwise remain tacit and b) offer a disruption of the norms of isolation and antagonism common to daily life in the SAWP.

\section{Embodied experiences of employment within Canada's SAWP}

This section will focus on aspects of the SAWP experience that highlight the importance of explicitly considering the embodied experiences of workers who find themselves at the nexus of precarious work (Vosko, 2006) and precarious citizenship (Goldring, Berinstein and Bernhard, 2009). It must be stated from the beginning that the physical labour that SAWP workers undertake on a daily basis is a deeply kinesthetic activity. Throughout this article I therefore make the case that any qualitative analysis of SAWP workers' experi- ences would benefit from an embodied approach to research, one that prioritizes the need to bring to the surface knowledge in the body that may otherwise remain tacit (Polanyi,

1983). Scholars such as Wacquant (2004) and Samudra (2008), for example, have developed approaches to qualitative research that treat the body as a primary site of cultural, social and political knowledge. In their work with male boxers and martial artists respectively, these researchers have examined the use of 'embodied ethnography' or 'thick participation' in developing rich descriptions of kinesthetic practices among research participants (Samudra, 2008: 665). Thinking beyond the manual labour itself, in the context of Canada's SAWP, an embodied approach to knowledge production also highlights particular forms of discipline that are unique to how temporary foreign worker programs in Canada have been administered historically, thus emphasizing an even more urgent need to actively engage workers' bodies in the research process. Specifically, the SAWP requires that workers remain with their state-approved employer for the duration of their contracts and that employers must provide on-site housing to their workers, essentially tethering workers' bodies both to their employers and to their worksites. This living-atwork arrangement maximizes workplace discipline by extending the invisible reach of employee management from the workplace to the intimate spaces of workers' homes and private relationships. For SAWP workers, this structure permeates every social interaction and may facilitate the development of habitual and embodied practices that can play an integral role in both upholding and resisting acceptable ways of being. Recent literature has examined how limiting the employment and citizenship rights of migrant farm work- ers is a key element in the bio-political control of temporary foreign workers in Canada on a societal scale (Perry, 2012b). The SAWP living-at-work arrangement demonstrates on a more intimate scale how SAWP policies impact workers' everyday experiences of 
employment in banal settings such as the workplace and the dormitory. The question remains of how this arrangement shapes workers' bodies in their daily routines of work, friendship and the mundane tasks of daily social reproduction.

Binding workers to a single employer for the duration of their contract is an essential dimension of SAWP workers' embodied experiences of employment (Horgan and Liinamma, 2017; Preibisch, 2004). Crucially, the SAWP contract stipulates that employers must provide housing to their workers (Employment and Social Development Canada, 2017). Worker dormitories are often physically attached to the worksite itself, ensuring workers' limited mobility on an everyday scale (Basok, 2002: 106-128; ReidMusson, 2017). In the context of contemporary mobile and migrant worker regimes, both in Canada and internationally, the purpose of dormitories is to 'attach single workers for short term capture' (Smith, 2003: 334). Studies globally have shown how migrant worker dormitories in the context of present-day global capitalism operate as a tool to maximize the control of temporary labour (Cravey, 1998; Pun, 2009). For workers who participate in Canada's SAWP, the intimate environment of the dormitory topples the binary of the public and the private as both workplace and household relationships collapse into a singular geographical site. Under this system, activities such as cooking, laundry, communicating with family members and the forging of friendships among workers and socializing in their off-work time more often than not occur on company property. As such, for SAWP workers, the simplest, most commonplace processes of daily social reproduction, what Katz (2001: 711) refers to as the 'fleshy, messy, and indeterminate stuff of everyday life' occur within the realm of the agricultural production unit and fall within the scrutiny and control of employers and even state officials.

Attaching workers to the worksite through the mechanism of the dormitory enables intimate invasions of state and employer control of the labour process, giving rise to what Foucault referred to as 'an entire micro-power concerned with the body' (Foucault, 1978: 146). This key insight from Foucault opens a window to understanding how state policies that restrict the mobility of migrant workers are performed in daily life through workers' interpersonal interactions with employers and fellow workers. From the SAWP living-atwork arrangement emerges a certain 'politics of intimacy' that permeates the social relations that develop in the program. The relationships that develop between workers are crucial to understanding the micro-political dynamics that shape daily life as a migrant worker in Canada. To borrow from Stoler's work on intimacies in the context of colonial relations (Stoler, 2006: 36), it is within these intimate relationships where regimes of labour and migration control are 'imposed, worked around, and worked out'. For SAWP workers, the performance of everyday life in the workplace/dormitory is not purely per- sonal but rather is 'infused with worldliness' (Pratt and Rosner, 2012: 3). Workplace and dormitory social relationships take on specific political and social meanings that are shaped by workers' experiences of international migration and confinement.

The SAWP living-at-work arrangement as it is described here has serious implications for workers' embodied experiences of work and employment. This arrangement ensures that workers' bodies become, to cite the vivid imagery of Harvey (2000: 117), a 'battleground' within which and around which political economic forces are continuously at play. State policies that constrain workers' mobility are performed not only at the international border, but are therefore also 'inscribed on the body in daily life where the state 
influences the body in the most intimate and far reaching ways...'(Mountz and Hyndman, 2006: 452). The work Bourdieu is useful here for reflecting on how everyday practices that evolve in this environment may produce what he coined habitus - a system of internalized dispositions that can mediate between social structures and everyday individual practices and interpersonal relations (Bourdieu, 1977: 81). Bourdieu describes habitus as a learned process of self-regulation that is environmentally determined (Bourdieu, 1977: 72). For workers employed in Canada's SAWP, the production of habitus evolves from embodied experiences of navigating the particular spatial organization of the SAWP workplace/dormitory. Developing a research design that captures and examines workers' embodied social relations may provide a unique lens through which to explore political processes related to migration and work, and the emotional and material effects these have on temporary foreign workers in Canada.

An embodied approach to research is embedded in feminist methodological traditions (Inckle, 2010) and is complimentary to feminist scholarship that highlights how people experience oppression primarily through the body (hooks, 1994). For the project described in this article, I have found inspiration in the words of bell hooks (1994: 139), who said: 'we must return to a state of embodiment in order to deconstruct the way power has been traditionally orchestrated'. I make the case here that a critical approach to deconstructing habitus through engaging the body in research encounters is a signifi- cant turn toward prioritizing the agency of research participants themselves (Maynes, Peirce and Laslett, 2008: 30-33). This is a move toward approaching the research encoun- ter not just as a site of knowledge production, but also as a process of reflecting on and challenging accepted ways of being. As such, an embodied approach toward research with migrant workers can contribute significantly to the development of anti-oppressive research methodologies (Brown and Strega, 2005) and 'decolonizing' approaches to adult learning (Ng, 2011). Paying attention to the complexities of participants' individual subjective worlds in the context of the workplace/dormitory by engaging the physical body may offer insights into the dynamics of worker habitus in Canada's SAWP, and significantly, may contribute to its potential transformation. Having established the methodological importance of approaching the body as a starting point for conducting qualitative research with temporary foreign workers in Canada in the following section I will lay the groundwork for developing a theatre-based approach to active research that seeks to achieve exactly that.

\section{Theatre as kinesthetic and embodied action research}

The use of the arts in qualitative research has been gaining legitimacy in recent years (Knowles and Cole, 2008). Within the wider category arts-based or arts-informed qualitative research there has been a keen interest in how to develop the use of the performing arts, particularly amongst ethnographers (Pelias, 2008). Proponents of performance inquiry argue that as 'the performer relies upon the body as a location of knowledge' (Pelias, 2008: 186), the use of performance in ethnographic research can be an 'intensely sensuous' (Conquergood, 1991: 180) methodological tool. In recent decades, this has been a methodological discussion primarily waged within the areas of communication studies and educational ethnography (Bagley, 2008; Denzin, 2009). A crucial 
development within this 'performance turn' in qualitative research has been a growing interest in the use of what has come to be known as performance ethnography (Denzin, 2009; Foster, 2012; Goldstein et al., 2014; Rossiter et al., 2011). The use of theatre has been gaining particular traction in this realm (Beck et al., 2011). The main question of performance ethnography relates to how to represent 'qualitative research tales' (Cancienne and Bagley, 2008: 170) beyond the boundaries of text as a way extending how ethnographers may disseminate and share data (Bagley, 2008; Jones, 2002). Within these debates, embodiment and kinesthetic awareness are topics that are often discussed in rela- tion to the effective representation of ethnographic data in ways that can provoke more empathic and accessible characterizations of fieldwork (Kontos and Naglie, 2006). What is still under-developed in this literature is how kinesthetic awareness may be employed in the generation of embodied knowledge with research participants in the field through movement and performance (Gray and Kontos, 2017). This article addresses this gap and replies to Denzin's (2009: 267) call to develop a performative praxis that is 'radically democratic, pedagogical, and interventionist' - a collaborative action research pedagogy that can privilege embodied experience and provoke critical education. This is the kines- thetic and embodied approach to qualitative research that I wanted to incorporate in my fieldwork with SAWP workers. As such, my intention in this article is to move these debates away from a predominant focus on dissemination toward discussions related to the development of critical performance methods in the realm of qualitative fieldwork. In this way, this project brings together distinct ideas from both arts-informed research and participatory action research.

While relatively overlooked within arts-informed research debates, there are a growing number of examples of action research projects that integrate the use of drama techniques in working directly with research participants (Conrad, 2004; Gallagher and Wessels, 2013; Guard et al., 2012; Norris, 2011; Nouvet et al., 2017; Quinlan, 2009; Tofteng and Husted, 2011). Increasingly, researchers involved in this work have been integrating the work of late Brazilian theatre director and educator Augusto Boal as adapted from his renowned theatre-based popular education system known as the Theatre of the Oppressed (Boal, 1985, 2002). Originally developed by Boal as a theatri- cal intervention in community and group development, a small contingent of scholars is transposing his work into a unique tool for participatory and action research. Through their engagement with Boal's work, these researchers have begun to develop a produc- tive method for cultivating a reflexive practice of knowledge production grounded in participants' embodied and collective experimentation with immediate life experiences (Quinlan, 2009). This typically involves the researcher facilitating basic theatre exer- cises or the creation of a collectively created play with a small group of research partici- pants with the intention of eliciting conversations around a given topic related to the research at hand (Norris, 2011). For Quinlan (2009: 120), who has used the Theatre of the Oppressed in research with healthcare workers, this technique proved highly effec- tive as a strategy for participatory engagement as, in her words, 'assumptions and inter- pretive categories, related to the social and material worlds of the constituent group, are made visible and critically reviewed by the participants'. In the context of knowledge generation, this method has been said to be particularly good at 'highlighting aspects of experience that had been in shadow, helping us to appreciate the drama and beauty of 
lives in our communities' (Brydon-Miller, Friedman and Gaya, 2011). What these researchers have found is that these collective experiences of physically engaging participants' bodies in the research process deliver a uniquely effective way of generating embodied personal narratives and of facilitating critical group conversations around sensitive topics that may otherwise be difficult to discuss.

There is a particular sensual quality to the process of theatre creation that I felt could be harnessed in my fieldwork with SAWP workers. As I have described earlier, I argue that any examination of the politics of intimacy that permeates SAWP workers' lives in the workplace and dormitory needs to incorporate knowledge that is tacit, embodied, and not easily translated into words. Simply put, as manual labourers, SAWP workers spend the majority of their time engaging their bodies in a deeply kinesthetic activity that over time becomes memory in their bodies (Samudra, 2008: 665). Workers come to experience their lives in the SAWP through the everyday sensory experiences of work and dormitory living. In their very everydayness, these experiences are both fundamental to shaping workers' impressions of life in the SAWP and yet may be so familiar as to be almost invis- ible. Day in and day out, workers' bodies both adapt to and resist life's daily pressures. It was my impression in designing this research that these were potentially integral experi- ences that would be difficult to access through interviews alone. This is particularly acute given SAWP recruitment practices that target workers with the lowest possible levels of formal education (Secretaría del Trabajo y Previsión Social, 2014). Given their work and limited education histories, SAWP workers may be more inclined to 'think kinestheti- cally' on the job, and may not be used to translating these experiences directly into inter- view responses (Samudra, 2008). I needed to integrate a research method that could engage participants at the level of 'sensations and perceptions' in such a way that would facilitate a critical dialogue with participants' embodied memories of work (Lewis, 2012:

56). Popular forms of art, such as Boal's Theatre of the Oppressed, can be particularly effective at creating a pedagogical and research environment where workers are not only mentally engaged, but physically engaged, in effect discarding 'the prejudice by which working-class activity is restricted to manual labour' (Bishop, 2012: 38). Focusing on an examination of workers' kinesthetic experiences of daily life provided a mechanism for accessing what Linds and Vetraino (2008: 16) have referred to as a certain 'sensitivity to the intuitive, the hither side of words'. In designing a research project that utilized theatre creation, my intention was to create a research environment that could prioritize the embodied, difficult to access elements of workers' experiences. By inviting participants to playfully involve their bodies in cooperative exploration I envisioned a process of discov- ery in which knowledge is not only produced collectively, but also one in which daily habits are continuously challenged and reinvented (Perry, 2012a). In so doing I incorpo- rated an embodied, participatory, and collective approach that was designed as an excur- sion by research participants into 'recollection and reflection' (Ng, 2006: 2). Through drama-based activities, I was able to incorporate the use of participants' actual bodies in research interactions. This approach to capturing respondents' embodied experiences of work and migration deepened my methodological commitment to prioritizing worker voice and experience. Approaching the body as a primary site of interrogation through theatre creation and performance provided a method for developing a somatic narrative, and thus a more nuanced understanding workers' lives. 
In this project, I invited migrant farm workers from Canada's hydroponic greenhouse industry located in Leamington, Ontario to participate in collective improvisation and playbuilding (Norris, 2011) grounded in the techniques derived from Theatre of the Oppressed. Participants were invited to explore questions related to the effects of constraining immigration policies and labour practices on their daily lives and interpersonal relationships. Over the course of six months, a small group of workers from Mexico joined me once a week in a local church basement on Sunday afternoons to participate in this theatre-based research collective. During this time, I was simultaneously conducting semi-structured interviews with a larger group of SAWP workers. These interviews helped to shape the discussions that took place and dramatic scenes that we created during the theatre workshops. In total I conducted 30 one-on-one interviews with workers and a total of 10 workers were involved in the theatrical portion of the project. Recruitment was mainly conducted through a local non-profit organization that provided free English classes for workers. A typical theatre-based session included workers' participation in several theatrical games and activities. I then led group discussions tying the experience of participating in these activities to participants' experiences of life in the SAWP, and to the interviews that I was simultaneously conducting with workers. Eventually, these dis- cussions led to the creation of several dramatic scenes depicting the experiences of a worker from Mexico in his first year in the program navigating the complex relations between state officials, employers and fellow workers. The content of these scenes were discussed at length and developed into a short play. Starting from participants' raw bod- ily experiences of life in the program meant that research participants could create a collective narrative grounded in real experiences of daily life. This was inspired by Norris' (2011: 31) claim that ' $\ldots$ improvisation can be a powerful form of inquiry' in which participants may 'phenomenologically reenact livedexperiences' (2011: 34). One research participant (Mauricio) commented on how this phase of the research was par- ticularly invigorating as he felt workers' were being given the opportunity to portray their experiences honestly. ${ }^{1}$ In his words, this group of research participants was able to capture what he called 'nuestro mero mole', which roughly translates from Mexican Spanish as 'our plain truth'. In this simple comment, Mauricio described his impression of legitimacy and authenticity that he felt the collective process of investigation grounded in kinesthetic exploration was able to generate. Engaging with the 'plain truth' of work- ers' lived experiences allowed for new personal and collective discoveries and offered moments of rupture from which could emerge challenges to accepted forms of everyday social interaction, or habitus. Simply put, coming together to actively create physical improvisations that metaphorically examined the 'politics of intimacy' that infuse the SAWP living-at-work arrangement provided a unique platform for engaging workers in participatory-style qualitative research.

\section{Theatre in action research with migrant farm workers in Canada}

Theatrical exploration began with non-verbal physical improvisations of workers' everyday lives and went on to include playbuilding and performance. Unlike other forms of perfor- mance ethnography, the development of a public performance was not prioritized. Instead, 
my intention was to develop a critical performance tool that could be used in the service of data generation and analysis among a small group of research participants. Downplaying verbal communication and inviting workers to express themselves physically followed Boal's (2002) insight that engaging with participants' lived experiences through embodied images and movements prioritizes a way of knowing that necessarily involves the body. This approach is also consistent with popular forms of education used by Mexican-American agricultural workers during the Chicano movement in California in the 1960s (Broyles- Gonzales, 1994). In her analysis of how participatory theatre was used in the context of political struggle and social movement at this time Broyles-Gonzales (1994: 15) highlights the importance of memory and the body as central vehicles of cultural transmission within Mexican oral culture. In her words, 'Memory should not be understood here as a cerebral, individualistic, psychological process, but in its collective and physical manifestation: as remembrance and transmission of the community's knowledge through that community's performance forms...'. A non-verbal and physical approach to storytelling such as Boal's thus provided a culturally appropriate means of accessing workers' embodied memories of work. This method offered a means of collectively examining tacit forms of knowledge that may otherwise have been difficult to discuss through more traditional forms of qualitative data gathering. This kinesthetic approach to data collection formed the basis for initiating a group dialogue among workers around how the SAWP working and living environment can impact the intimate social relationships that develop between coworkers. The research arena was thus transformed into a lively and vigorous pedagogical event.As such, more than asking questions and probing for details, my role as a researcher was to encourage partici- pants to engage in a process of critical reflection grounded in 'embodied critique and pos- sibility' (Linds, 2006: 123). In this section I discuss several key moments from my research process in order to demonstrate how engaging research participants kinesthetically provided both rich descriptions of workers' everyday lives and a platform for critical reflection.

\section{Examining SAWP co-worker relations through theatre creation}

One central theme that emerged from both the interviews and the theatrical workshops was the topic of antagonistic relationships that seem to habitually develop between co-workers in the intimate spaces of the SAWP. Over the course of 10 weekly theatre as research sessions, workers improvised, created images, and developed a play that examined how the SAWP working and living environment impacts workers' relationships to each other. During these sessions workshop participants identified how a culture of intense competition develops between workers, explored the social and psychological impacts of hostile relationships at home and at work, questioned whether workers themselves were somehow complicit in nurturing a competitive environment, and examined the social costs of workers speaking out against it. These explorations culminated in the collective creation of a play that followed the experiences of a fictional protagonist named Jaime, a rookie SAWP worker from Mexico navigating his way through his first year in the program. The crest of the play focused on how Jaime decided to respond to his Canadian boss who was harassing him for not working fast or efficiently enough. 
The play that workers created presented Jaime as lagging behind two of his co-workers, both of whom had been participating in the program and returning to the 
same greenhouse operation over the course of many years. Participants developed the workplace scene in such a way that demonstrated how more experienced workers were able to move faster and thus could incur less attention from the employer. At one point the employer entered the scene and noticed that Jaime was having trouble maintaining the pace of his co-workers and that he was not doing his job properly. He began to follow Jaime, all the while yelling at him for not picking correctly or not moving fast enough. Eventually, the employer stopped all of the workers in order to reprimand Jaime directly. In order to get a sense of Jaime's thought processes in this moment, during one of the rehearsals I asked the worker (Enrique) who was playing Jaime to explore his character's options by examining his thoughts and feelings through attempting to voice aloud his character's inner monologue, an established Theatre of the Oppressed technique (Boal, 2002: 19). Here is an example of what Jaime's was thinking as he was getting harassed by his employer (as created by Enrique):

Oh, how much he makes me angry that damned boss. He walks behind me all the time. I'm still new and he never gives me the chance to learn. Always he's right behind me. How I can't stand how I come here and they discriminate against me. I'll show him... I'll show him... if he continues to reprimand me I'm going to drop him to the ground with a tomato. To tell the truth, I regret coming here. He's making my blood boil. This is shit. I'm going back to Mexico. If I knew it would be like this I would never have come. ${ }^{2}$

As a group, the participants present in this workshop discussed how Jaime's internal monologue captured both the desire and the reluctance of an SAWP worker to speak out about discrimination and harassment in the workplace. The group talked about how factors such as the possibility of getting fired and sent back to Mexico or the likelihood of getting ritually chastised by his co-workers for causing trouble may be enough for Jaime to decide to remain silent. However, after several rehearsals, the group decided that in the play Jaime should confront the boss directly in order to fully explore the potential consequences. In the surrounding scenes, research participants framed this small act of rebellion within the larger backdrop of a hyper-competitive workplace and dormitory environment, and as such were able to examine the questions of worker defiance and accommodation in a somewhat wider social context.

In the scene that participants ultimately created, Jaime became visibly upset and openly criticized the employer for not providing adequate training, and claimed that that was why he was not able to keep up with his more experienced co-workers. Fearful that the employer would punish the workers as a group for Jaime's perceived transgression, his co-workers refused to translate Jaime's words into English, and instead responded with things like, 'oh I didn't hear what he said. I was working' (Co-worker 2). This made the employer more upset, and he confronted Jaime's co-workers for not showing Jaime the proper way to do the work. The boss threatened to contact Mexican officials the following day in order to intervene and possibly repatriate Jaime to Mexico if his work did not improve. In a huff, the employer stormed out of the greenhouse. Once the employer was gone, Jaime's two co-workers confronted Jaime about opposing the employer. Co-worker 1 (played by Javier) said: 'Why did you react so insultingly? That's not good, man. At the beginning you have to behave'. Co-worker 2 (played by Joachín), who was 
playing the role of greenhouse foreman (also an SAWP worker), responded with the following line: 'And that represents a problem for us too, because he wanted me to translate what you were saying, and you were saying rude things. I won't repeat those to him'. In addition, they claimed that the employer may punish them all for being accomplices, and if that were to happen it would be entirely Jaime's fault. These co-workers expressed anger against Jaime for disrupting the performance of expected roles, at once establishing the societal norm and squashing the potential risk that they felt Jaime represented to their collectively agreed upon performance of deference.

On their return to their shared dormitory, the foreman gave Jaime a hard time about wanting to attend English classes after work. He taunted Jaime with lines like 'Instead of going to English class you should stay and clean the oven. Look, the floor is dirty'. When Jaime eventually left the bunkhouse in order to attend classes, his co-workers talked about him behind his back concerning how he got them into trouble with the boss earlier and how if he does not improve at work they will all be dealing with the Mexican consu- late. 'And even with that problem looming', complained Jaime's co-worker, 'he still goes to learn English'. On his way back from English classes, Jaime overheard some of what they were saying, and when he entered the kitchen he confronted his co-workers, who teased him for wanting to learn English and insinuated that he was just interested in flirting with the pretty teachers. His co-workers warned him not to go to English classes the following night, but instead to stay in and clean so as to make up for what had happened earlier in the greenhouse. Jaime's co-worker said: 'Tomorrow you don't go to English classes. You have problems at work, and if some co-worker tells the boss that you are not doing your share of the cleaning, that will make it worse. Tomorrow stay and clean'. Feeling dejected, Jaime went to his dorm and called his wife. This was Jaime's side of the conversation he had with her:

I'm not really happy because the work is hard. The boss yelled at me three times today. And my co-workers, they've been here a long time and they don't like being around me. They get along well with the boss. I feel discouraged. I regret coming, but I have to do it for the kids, because I have no work back home. Everything that is happening is for the best. When I get back to Mexico I'll go to the Ministry of Labour and try to get sent somewhere else. I don't want to come back here. Good night, my love. I love you.

The dormitory scene ended with Jaime lying on his cot unable to sleep; alone in his thoughts yet surrounded by his sleeping co-workers.

\section{Discussion: bringing forth tacit knowledge and challenging habitus}

Starting with participants' portrayal, through movement, of the hard physical labour that workers undertake on a daily basis provided a particularly fruitful entry point to examining the internal landscapes of workers' lives and subsequently the relationships that develop in managed agricultural labour migration schema such as Canada's SAWP. In particular, the collective development of the fictional protagonist provided a vital lens to observing workers' decision-making processes at work and in the dormitory. As such, an 
embodied and kinesthetic approach to qualitative inquiry revealed how the body, as a social and political 'battleground' (Harvey, 2000), can be a uniquely productive means of accessing tacit knowledge and addressing the 'politics of intimacy'that permeates SAWP workers' lives. To this end, the inner monologue activity described above offered a crucial opportunity. In this moment Enrique portrayed a particularly difficult moment at work, then paused, reflected on his thoughts and verbally performed his innermost feelings for the purposes of character development and group analysis. By honing in on Enrique's most intimate personal reflections, participants were able to discuss the complex array of issues workers must consider when deciding whether or not to speak out against a perceived injustice. The collective decision to have Jaime openly confront his employer offered further opportunities to elicit opinions and analyses concerning the development of a culture of acquiescence. Jaime's conversation with his wife in the final scene highlighted his feelings of isolation, the difficulty of adjusting to his new situation, and his frustration with what he interpreted as his co-workers' alignment with the employer. At the same time, he provided a reflection on how the need to support his fam- ily may oblige him to put up with a bad situation. The end is left open-ended. We are unsure as to whether Jaime will find his own path or give into the pressures to conform, thus facilitating a gateway for further group discussion. Exploring the inner lives of workers and placing these within the wider socio-political context of SAWP disciplinary practices elicited in-depth deliberations that dealt explicitly with the contours of migrant worker agency - discussions that would be difficult to facilitate through interviews. Engaging directly with Jaime's inner monologue led to a collective examination of how antagonistic relationships can develop among workers. Theatrical improvisation brought the intimate and embodied dimensions of the SAWP living-atwork arrangement to the foreground. The 'aesthetic event' of play-creation with workers themselves generated a research environment in which dialogue could effectively take place (Lewis, 2012: 60). This environment fostered collaboration and encouraged research participants to come together to examine the more intimate elements of their lives and to connect these to the experiences of the collective. Theatrical improvisation was harnessed into a potent form of qualitative inquiry and resulted in a rich collective foray into tacit knowledge, mem- ory, reflection and experimentation.

The dialogue sparked by kinesthetic engagement and artistic expression proved to be a valuable springboard for both disrupting and critiquing the development of worker habitus. In having research participants gather together to creatively examine each other's experiences of migration, harassment, survival, and resistance, data collection was thus turned into a process of learning, creativity, and group expression. This provided a unique disruption to workers' expected performance of 'knowing one's place' and 'staying there' (Bourdieu, 1977: 82). Investigating workers' experiences through physicalization and improvisation was itself a disruption of the idea, first articulated in Plato's Republic, that only the 'middle classes have the leisure time to think and critically reflect' (Bishop, 2012: 38). In the context of Canada's SAWP, migrant farm workers coming together to laugh, play, and take part in an artistic event signified a breach in the accepted norms of control, and represented an essential step toward a process of decolonizing research (Kovach, 2005). Working kinesthetically and artistically meant treating participants as embodied subjects and incorporating both mind and body in a collective 
reflection on how hegemonic ideologies are performed out of habit. $\mathrm{Ng}$ (2011: 361) refers to these types of pedagogical encounters as 'decolonizing education', or moments of interruption that serve to interrogate

...how we, as individuals living within and being part of collectivities reproduce and sustain systems of oppression... through normalized patterns of behaviour that have been developed over time that have become 'natural', automatic and unconscious actions and ways of being in the world.

The process of play-creation itself was anathema to the reproduction of worker habitus and promoted in its stead a 'habit of being where you were not supposed to be' (Lewis, 2012: 40). More than just disrupting worker habitus through the process of artistic collaboration, however, collective creation also facilitated a critique of patterns of behaviour that reproduce systems of control. These moments of critique can be seen for example in workers' decision to portray the development of co-worker antagonism not as a clash of individual personalities, but as a symptom of structural power imbalances and as an effect of precarity in both work (Jaime's reflection on his economic need to adapt) and citizenship (workers' physical tethering to the employer). This analysis runs counter to the organization of inter-worker relations that the SAWP engenders: relation- ships often characterized by social isolation, competition and worker-on-worker antago- nisms. As such, the research process became not only a process of discovery, but of recovery (Park, 1993). What was recovered was participants' capacity to step back and observe processes of control and experiment with new subject positions and possibilities for social transformation.

\section{Conclusion}

Incorporating a theatre-based approach to qualitative research design with migrant farm workers provided this research project with a very useful instrument for engaging the collective voice of research participants. It provided an avenue for accessing tacit and embodied forms of knowledge and a springboard for eliciting a reflection on and to a certain extent a critique of Canada's SAWP living-at-work arrangement from the perspective of workers themselves. Specifically, this was achieved through an examination of a particular politics of intimacy that imbues worker-on-worker relations - a politics uncovered by engaging workers' bodies directly in a theatrical exploration of their lives in Canada's agricultural labour migration program. Participants examined through play creation and subsequent group discussions how the intimacy generated by Canada's SAWP living-at-work arrangement produces an ideal environment for workers to collectively work out the performance of an accepted way of being. This is a way of being characterized by flexibility, compliance and accommodation in the face of employer hostility and the state-mandated confinement of workers' bodies to employer property. What was worked out in the development and performance of this jointly created play, however, was participants' unguarded examination of worker habitus and its development. This collective examination of Canada's SAWP by workers themselves could itself be described as a challenge to the prescribed subject position of 'migrant worker'. 


\section{Funding}

Funding Sources Social Sciences and Humanities Research Council of Canada Award number 752-2011-2626.

\section{Notes}

1. All workers were provided with pseudonyms.

2. All direct participant quotes have been translated to English from the original Spanish.

\section{References}

Bagley C (2008) Educational ethnography as performance art: towards a sensuous feeling and knowing. Qualitative Research 8(1): 53-72.

Basok T (2002) Tortillas and Tomatoes: Transmigrant Mexican Harvesters in Canada. Montreal: McGill-Queen's University Press.

Beck JL, Belliveau G, Lea GW, et al. (2011) Delineating a spectrum of research-based theatre. Qualitative Inquiry 17(8): 687-700.

Bishop C (2012) Arificial Hells: Participatory Art and the Politics of Spectatorship. London: Verso.

Blumenfeld-Jones D (1995) Dance as a mode of research representation. Qualitative Inquiry 1(4): 391-401.

Boal A (1985) Theatre of the Oppressed. New York: Theatre Communications Group.

Boal A (2002) Games for Actors and Non-actors. 2nd ed. London: Routledge.

Bourdieu P (1977) Outline of a Theory of Practice. Cambridge: Cambridge University Press.

Brown L and Strega S (2005) Research as Resistance: Critical, Indigenous, and Anti-oppressive Approaches. Toronto: Canadian Scholars' Press/Women's Press.

Broyles-Gonzales Y (1994) El Teatro Campesino: Theatre in the Chicano Movement. Austin: University of Texas Press.

Brydon-Miller M, Freidman V and Gaya P (2011) The changing landscape of arts and action research. Action Research 9(1): 3-11.

Cancienne M and Bagley C (2008) Dance as method: the process and product of movement in educational research. In: Liamputton P and Rumbold J (eds) Knowing Differently: Arts-based and Collaborative Research Methods. New York: Nova Science Publishers, Inc, 169-187.

Conquergood D (1991) Rethinking ethnography: toward a critical cultural politics. Communication Monographs 58: 179-194.

Conrad D (2004) Exploring risky youth experiences: popular theatre as a participatory, performative research method. International Journal of Qualitative Methods 3(1): 1-24.

Cravey AJ (1998) Women and Work in Mexico's Maquiladoras. Lanham: Rowman \& Littlefield Publishers.

Denzin N (2009) A critical performance pedagogy that matters. Ethnography and Education 4(3): 255-270.

Employment and Social Development Canada (2017) Agreement for the employment in Canada of seasonal agricultural workers from Mexico - 2017. Available from: https://www.canada.ca/ content/dam/canada/employment-social-development/migration/documents/assets/portfolio/ docs/en/forein_workers/hire/seasonal_agricultural/documents/sawpmc2017.pdf 
Foster V (2012) Pantomime and politics: the story of a performance ethnography. Qualitative Research 13(1): 36-52.

Foucault M (1978) The History of Sexuality Volume 1: An Introduction. New York: Pantheon Books.

Gallagher K and Wessels A (2013) Between the frames: youth spectatorship and theatre as curated, 'unruly' pedagogical space. Research in Drama Education: The Journal of Applied Theatre and Performance 18(1): 25-43.

Goldring L, Berinstein C and Bernhard JK (2009) Institutionalizing precarious migratory status in Canada. Citizenship Studies 13(3): 239-265.

Goldstein T, Gray J, Salisbury J, et al. (2014) When qualitative research meets theater: the complexities of performed ethnography and research-informed theater project design. Qualitative Inquiry 20(5): 674-685.

Gray J and Kontos P (2017) An aesthetic of relationality: Embodiment, imagination, and the necessity of playing the fool in research-informed theatre. Qualitative Inquiry. Advance online publication. DOI: 10.1177/1077800417736331.

Guard J, Martin D, McGauley L, et al. (2012) Art as activism: empowering workers and reviving unions through popular theatre. Labor Studies Journal 37(2): 163-182.

Harvey D (2000) Spaces of Hope. Berkeley: University of California Press.

hooks b (1994) Teaching to Transgress: Education as the Practice of Freedom. London:

Routledge. Horgan M and Liinamaa S (2017) The social quarantining of migrant labour: everyday effects of tem-

porary foreign regulation in Canada. Journal of Ethnic and Migration Studies 43(5):713-

730. Inckle K (2010) Telling tales? Using ethnographic fictions to speak embodied 'truth'.

Qualitative

Research 10(1): 27-47.

Jones J (2002) Performance ethnography: the role of embodiment in cultural authenticity. Theatre Topics 12(1): 1-15.

Katz C (2001) Vagabond capitalism and the necessity of social reproduction. Antipode 33(4):

709-728.

Knowles JG and Cole AL (eds) (2008) Handbook of the Arts in Qualitative Research: Perspectives, Methodologies, Examples, and Issues. London: SAGE.

Kontos P and Nagle G (2006) Expressions of personhood in Alzheimer's: moving from ethnographic text to performing ethnography. Qualitative Research 6(3): 301-317.

Kovach M (2005) Emerging from the margins: indigenous methodologies. In: Brown L and Strega

S (eds) Research as Resistance: Critical, Indigenous, and Anti-oppressive Approaches,

Toronto: Canadian Scholars Press Inc, 19-36.

Lewis TE (2012) The Aesthetics of Education: Theatre, Curiosity, and Politics in the work of

Jacques Rancière and Paulo Freire. London: Continuum International Publishing Group.

Linds W (2006) Metaxis: dancing (in) the in-between. In: Cohen-Cruz J and Schutzman M (eds)

A Boal Companion: Dialogues on Theatre and Cultural Politics. New York:

Routledge,

114-124.

Linds W and Vettraino E (2008) Collective imagining: collaborative storytelling through image theatre. Forum Qualitative Sozialforschung/Qualitative Social Research 9(2). Available from: http://www.qualitative-research.net/index.php/fqs/article/view/400. DOI: 10.17169/ fqs-9.2.300.

Maynes MJ, Peirce JL and Laslett B (2008) Telling Stories: The Use of Personal Narratives in the Social Sciences and History. Ithaca: Cornell University Press. 
Mirchandani K, Vosko LF, Soni-Sinha U, Perry JA, Noack AM, Hall RJ, Gellatly, M (2016) Methodological k/nots: Designing research on the enforcement of labor standards. Journal of Mixed Methods Research. Advance online publication. DOI: $1177 / 1558689816651793$. 
Mountz A and Hyndman J (2006) Feminist approaches to the global intimate. Women's Studies Quarterly 34(1/2): 446-463.

Ng R (2011) Decolonizing teaching and learning through embodied learning: toward an inte- grated approach. In: Valences of Interdisciplinarity: Theory, Practice, Pedagogy. Edmonton: Athabasca University Press, 343-366.

Norris J (2011) Playbuilding as Qualitative Research: A Participatory Arts-based

Approach.

Walnut Creek: Left Coast Press.

Nouvet E, Sinding C, Graham C, Vengris J, Fudge Schormans A, Fullwood A, Skeene M (2017). What are you (un)doing with that story? Qualitative Social Work. Advance online publication. DOI: $10.1177 / 1473325017735884$.

Park P (1993) What is participatory research? A theoretical and methodological perspective. In: Park P, Brydon-Miller M, Hall B, et al. (eds) Voices of Change: Participatory Research in the United States and Canada, Toronto: OISE Press, 1-19.

Pelias R (2008) Performative inquiry: embodiment and its challenges. In: Knowles G and Cole A (eds) Handbook of the Arts in Qualitative Research: Perspectives, Methodologies, Examples, and Issues. Thousand Oaks: SAGE, 185-194.

Perry JA (2012a) A silent revolution: 'Image theatre’ as a system of decolonisation. Research in Drama Education: The Journal of Applied Theatre and Performance 17(1): 103-119.

Perry JA (2012b) Barely legal: Racism and migrant farm labour in the context of Canadian multiculturalism. Citizenship Studies. 16(2): 189-201.

Polanyi M (1983) The Tacit Dimension. Gloucester: Peter Smith.

Pratt G and Rosner V (2012) Introduction: the global and the intimate. In: Pratt G and Rosner V (eds) The Global and the Intimate: Feminism in Our Time. New York: Columbia University Press, 1-30.

Preibisch K (2004) Migrant agricultural workers and processes of social inclusion in rural Canada: encuentros and desencuentros. Canadian Journal of Latin American and Caribbean Studies 29(57-58): 203-239.

Pun N (2009) The making of a global dormitory labour regime. In: Murphy R (ed)

Labour

Migration and Social Development in Contemporary China, London: Routledge, 154-170.

Reid-Musson E (2017) Grown close to homeTM: Migrant farmworker (im)mobilities and unfreedom on Canada family farms. Annals of the American Association of Geographers. Advance online publication. DOI: 10.1080/24694452.2016.1261683.

Rossiter K and Godderis R (2011) Finding the necessary distance: theorizing ethnographic research-based theatre. Journal of Contemporary Ethnography 40(6): 648-677.

Quinlan E (2011) Contemporary challenges to caring labour and time-honoured transformative tools: workplace bullying and the Theatre of the Oppressed. Just Labour: A Canadian Journal of Work and Society 17/18: 83-105.

Quinlan E (2009) New action research techniques: using participatory theatre with health care workers. Action Research 8(2): 117-133.

Samudra J (2008) Memory in the body: thick participation and the translation of kinesthetic experience. American Ethnologist 35(4): 665-681.

Secretaría del Trabajo y Previsión Social (2014) Subsecretaria del Empleo y Productividad Laboral Coordinacion General del Servicio Nacional del Empleo: Programa de Trabajadores Agrícolas Temporales México-Canadá. Available from: http://www.stps.gob.mx/bp/secciones/conoce/areas_atencion/areas_atencion/servicio_empleo/trabajadores_agricolas.html

Smith C (2003) Living at work: management control and the dormitory labour system in China. Asia Pacific Journal of Management 20(3): 333-358.

Smith C and Pun N (2006) The dormitory labour regime in China as a site for control and resistance. The international journal of human resource management 17(8): 1456-1470. 
Stoler AL (2006) Tense and tender ties: the politics of comparison in North American History and (post) colonial studies. In: Stoler AL (ed) Haunted by Empire: Geographies of Intimacy in North American History. Durham, MD: Duke University Press, 23-70.

Tofteng D and Husted M (2011) Theatre and action research: how drama can empower action research processes in the field of unemployment. Action Research 9(1): 27-41.

Tuck, E (2008) Suspending damage: A letter to communities. Harvard Educational Review. 79(3): 409-427.

Vosko LF (2006) Precarious Employment: Understanding Labour Market Insecurity in Canda. Montreal: McGill-Queen's University Press.

Wacquant L (2004) Body and Soul: Notebooks of an Apprentice Boxer. Oxford: Oxford University Press.

\section{Author Biography}

J. Adam Perry completed his $\mathrm{PhD}$ at the Ontario Institute for Studies in Education at the University of Toronto, where he utilized a participatory and performance-oriented research methodology with migrant farm workers to explore social problems emerging from policies and practices related to state-managed labour migration in Canada's agricultural industry. He is currently a postdoctoral research fellow cross-appointed with the School of the Arts and the School of Social Work at McMaster University in Hamilton, Canada. 